\title{
THE MAN AT THE SELF-PAINTED WINDOW
}

Yuwono, Edi ${ }^{1}$ and Irawan, Stefanny ${ }^{2}$

1,2) English Department, Faculty of Letters, Petra Christian University, Siwalankerto 121-131, Surabaya 60236, East Java, INDONESIA

e-mails: ediyuwono@hotmail.com; stefanny@petra.ac.id

\begin{abstract}
This creative project is an autobiographical novel that tells the story of Hero Widjaja, a Chinese Indonesian man who embarks on his journey to Hong Kong, Macau, and Mainland China to find his true identity. Having raised in a pretty conservative Chinese Indonesian family background, Hero learns that there is an unfinished business in finding his identity as a Chinese Indonesian man. His parents unconsciously indoctrinate him to identify himself just like Mainland Chinese people. On the other hand, Hero surely does not have Chinese citizenship or even speak Mandarin. One morning, his father offers him a free trip to visit his relatives in Mainland China. Keeping the desire to find his true identity, Hero decides to take the trip and prove it himself whether he is eligible to regard himself as Chinese. I decide to use Erikson's stages of psychosocial development to identify Hero's identity crisis. This theory aims to help me create problems and believable characterization for my characters to represent the identity crisis that Chinese Indonesian people may have in real life. As for the genre, I decide to choose biographical novel as the genre of my creative work. I mix my personal family experiences as a Chinese Indonesian man with fictional elements so that I can still catch my readers' attention from the beginning to the end.
\end{abstract}

Keywords: Autobiographical novel, self identity, identity crisis, stages of psychosocial development, Chinese Indonesian.

\section{INTRODUCTION}

Most of the Chinese descendants in Indonesia, as well as in other Southeast Asian counties and the United States, are from Fujian province and speak Min Nan dialect in a daily basis. Among Chinese Indonesian communities, it is common for Chinese Indonesian people to call themselves 'tenglang'. 'Tenglang' here is the spoken Min Nan dialect for 'tángrén' or 唐人, which literally means a person from Tang dynasty. It refers to Chinese people in Mainland China. In addition to that, they distinguish themselves from native people in Indonesia and call native Indonesian people as 'hoana'. It derives from the spoken Min Nan dialect for 'făn zì' (番仔), which means local Malay people (Chandradinata, 2009). Learning from these two terms, it proves that there has been a misconception that most Chinese Indonesian people have lived with for decades. Chinese Indonesian people, for sure, are not 'tángrén' or Chinese people in Mainland China.

In his essay published in Bahasa Indonesia, "Krisis Identitas Etnis Cina di Indonesia", DP Budi Setyo (2002) exclaims that there is an indication of an unfinished process among Chinese Indonesian people in identifying their identity. It can be seen from the fact that the majority of Chinese Indonesian people still identify themselves as Chinese people even though they do not meet the major qualifications to be Chinese people in general. Most of the Chinese Indonesian people do not speak Mandarin in their daily basis; all of them absolutely do not hold Chinese citizenship, either. Hence, it clearly shows that Chinese Indonesian people are not qualified enough to be regarded as Chinese people in general.

Looking back through the history, this invalid identification is related to the oppression that Chinese Indonesian community faced during either colonialism or independence (Susetyo, 2002). According to Bachrun and Hartanto (2000), all efforts that Chinese Indonesian people had done in order to be fully accepted as Indonesian people have been completely ruined by the May 1998 riots. Unlike in the Philippines and Thailand where Chinese descendants have merged in the society and become native people, Chinese Indonesian communities in Indonesia are still struggling to find their identity in the society (Susetyo, 1999).

I would like to create a creative work that brings up the issues of Chinese Indonesian identity. Basically, this creative project was initially inspired by my previous trip to China. In the end of January to the middle of February 2016, I got the opportunity to meet my paternal extended family residing in Quanzhou city, Fujian province. While I was socializing with them, I found out that they, 
as well as people from Mainland China in general, do not regard me as a Chinese man no matter I have the same Chinese blood flowing in my body. They introduced me to the neighbors as an Indonesian relative, which was somehow shocking for me in the beginning. I got used to telling everyone I was Chinese in Indonesia, and yet my relatives in China introduced me to their neighbors as the Indonesian relative.

I intended to recount this trip in a form of novel. The length of a novel is just perfect to provide me some space to put my ideas on appropriately. The trip that I had that inspired me to write this work of art was full of different emotions and important moments to portray perfectly. There were many thoughts and feelings that I would like to express in detail through my work of art, so I needed a big space for my project. Moreover, a novel enabled me to freely capture every moment in which other forms of art might not be able to help me capture entirely. I am not used to expressing ideas with the strict format and writing technique of screenplay and stage play writing. In fact, writing a screenplay makes me feel like my creativity is bounded, which I do not want it to happen when I write this project. Hence, a novel was absolutely the best tool for me to express my ideas more appropriately and comfortably.

For the genre, my book is an autobiographical novel. An autobiographical novel is a form of novel using autofiction techniques, or the merging of autobiographical and fiction elements (Thayalamoorthy \& Ratchagar, 2016). My creative work basically focuses on my trip as a Chinese Indonesian man who starts to question his own identity after visiting Mainland China, Hong Kong, and Macau. It revolves around the moment when I visited China in the end of January to the middle of February 2016. In writing the story, I have decided to fictionalize some aspects of my life, including changing age, personal features, and some of the family member profiles. It is because I learned that keeping the juiciest bits and tossing the less-than-interesting parts into the compost is the smart way to use a piece of truth to its full fictional advantage (Houston, 2012). By fictionalizing some aspects and characters of the story, I intended to make the story more dramatic and interesting for my readers to follow.

In terms of the marketing consideration, autobiographical novel also seem to sell very well in Indonesian market, both Indonesian-language and English-language books, and Western market. As for Indonesian-language books, readers in Indonesia are more familiar with the term biographical books. As cited in Kompasiana.com (2015), Husni Syafie, the General Secretary of IKAPI or the association of publishing companies in Indonesia, says that any biographical books dominate almost half of the total book sales in Indonesian market. He adds that half of top ten best-selling books in Indonesia are always occupied by biographical books. From this fact, I believe that my novel, which is autobiographical book, will also get a place in Indonesian readers.

Having observed the marketing consideration for autobiographical novel, my target market will be all Indonesian people who read English books, either Chinese Indonesian or non-Chinese Indonesian people, who are interested in cultural studies, especially in Chinese Indonesia culture. Since my novel will try to uncover the life of Chinese Indonesian people and their struggles to find their identity, this novel is considered serious novel with lots of information the readers can acquire as they follow the story. People with interests in Chinese Indonesian culture will be most welcome to read the novel and get involved in discussions provided throughout the plot.

The statements of the problems in this project are; what consequences the identity crisis among Chinese Indonesian people brings, how Chinese Indonesian parents in Indonesia have a role in shaping identity for the Chinese Indonesian people, and how important it is for Chinese Indonesian people to understand their own identity and try to live peacefully with it. I answered the statements of the problems in my purposes of the creative work by showing that identity crisis in Chinese Indonesian community brings harmful impacts to themselves at present to the future. I also showed that most of the conservative-minded, uneducated Chinese Indonesian elders usually introduce the 'wrong' identity to the younger generations from a very early age that they are just like Mainland Chinese, which can often make confusion and wrong perception to the young generation about their true identity. Besides, I also showed in the end that understanding their own identity more and living peacefully with it can be beneficial for the life of Chinese Indonesian people.

The theory that I used in this creative work is Erik Erikson's stages of psychological development. Erikson's stages of psychological development identify eight phases that a healthy developing individual should pass through from infancy to late adulthood. Each individual is 
expected to master the challenges in each stage. Every stage will build upon the successful completion of earlier stages. However, mastering a stage is not required to advance the next stage. The outcome of one stage is not permanent and can be modified by later experiences. Nevertheless, the unsuccessful completion of earlier stages will reappear as problems in the future. Each stage will be characterized by a psychosocial crisis of two conflicting forces and a virtue. If an individual successfully reconciles the two forces in each stage and favors the first mention force, the individual completes the stage and acquires the corresponding virtues (Crain, 2011).

In my writing, I applied some identified issues from this theory in order to make relevant and convincing conflicts. I believe this theory could also help me come up with appropriate characterization for my characters, especially for my main protagonist, Hero Widjaja. Since this creative work was an autobiographical novel, I surely needed to create a comprehensive background of my main protagonist to make it convincing and help me convey my messages more effectively. Thus, I created identity crisis from three different stages from Erikson's theory, which were the fourth, fifth, and sixth stages.

The fourth stage is at school age. It starts from the age 5 to 12 . In this stage, school and sports are the examples of activities conducted by the child. The child usually begins to have significant relationship with neighbors and people at school. They also start to question 'Can I make it in the world of people and things?' The forces that might construct psychosocial crisis in this stage are industry and inferiority (Macnow, 2014). If a child fails to enter into the fifth stage from this stage with more industry than inferiority, the child will lack the virtue of competence into the remaining life stages.

In regards to Erikson's fourth stage of psychosocial development, my main protagonist, Hero Widjaja, must deal with a traumatic experience in May 1998 riots. The riots happen when he is six years old. At that time, Hero needs to leave the country with her sister, running away from the people who want to harm his family. In times when he supposedly starts to ask 'Can I make it in the world of people and things?', he must experience discrimination and rejection from his own country instead. Later in the story, it would also be explained that Hero feels a bit of culture shock in Singapore for the reason that he does not speak English fluently when his 6-yeard-old self first moves there. He cannot communicate with his schoolmates in his early years of living there, resulting him barely having friends. It somehow makes him feel inferior in the sense that he always lacks selfconfidence and shy when it comes to communicating with others. Due to his feeling of inferiority, he often feels he is unwanted and lonely.

At the age of 13 to 19, an individual enters the fifth stage. In the adolescence, an individual starts to ask 'Who am I? Who can I be?'. An adolescent also begins to learn to have social relationship. Peers and role models are likely to have the most significant relationship with the individual in this stage. Identity and role confusion serve as the forces that might create psychosocial crisis in this stage (Ibid). Erikson is credited with coining the term identity crisis from his observation in issues within this stage of development (Gross, 1987). When an adolescent fails to enter into the sixth stage from this stage with more identity than role confusion, the child will fail to carry the virtue of fidelity into the remaining life stages.

Concerning the fifth stage of psychosocial development, Hero is called to go back by his family to Indonesia at the age of 13. In this stage, Erikson argues that people in adolescence will likely to ask, 'Who am I? Who can I be?' However, the situation is a bit tricky for Hero. In his adolescence, he finds himself in the confusion about who he is. He is from Indonesia, but he has to leave his country because of unstable political situation that might harm his family at the age of six. While he gets to regard himself as Singaporean, he has to go back to Indonesia after living abroad for six years. As soon as he goes back to Indonesia, he must get accustomed to living with his parents again, who constantly call themselves as Chinese. In this stage, Hero then suffers from role confusion. He is not sure he is Chinese, Singaporean, or Indonesian. In terms of family life, he is also not sure about his role as a child. Prior to that, he lives separately from his parents for six years, which makes his relationship with his parents more distant. Other than that, he realizes that his father is really fond of his elder brother as the first son in the family, which makes him feel he cannot find father figure in his family life. Due to these problems, he always feels insecure about himself that he lacks protection - both from the government and family — since he never thinks that the Indonesian 
government provides him what he needs as a citizen and that his father never stands up for him as a child.

The sixth stage happens when the individual is in his or her early adulthood, approximately around 20 to 39 years old. The question 'Can I love?' comes out in this phase. The individual also starts to get involved in romantic relationships here. He or she starts to have the most significant relationships with partners or friends. The psychosocial crisis is constructed by either intimacy or isolation (Macnow, 2014). If an individual fails to enter into the seventh stage from this stage with more intimacy than isolation, the individual will not obtain the virtue of love into the remaining life stages.

Talking about the sixth stage, Hero is now 24 , living in his early adulthood. He is struggling to finish his task to complete his sixth stage according to Erikson's theory. At this point of his life, Hero is having an issue with isolation. He starts to ask 'Can I love?' at this point, and it brings issues with his father, who is a typical conservative Chinese Indonesia family. Hero is romantically linked with Eri Fujiwara, a Japanese girl he happens to meet in his travel to Japan. Hero's father grows up listening to his own father's stories about how cruel Japan is for having killed thousands of Chinese people at war. As a man who believes he is Chinese, Hero's father certainly dislikes the idea that his son is dating a Japanese girl. At this point, Hero's relationship with his father gets worse. He thinks that he is isolated in the sense that he cannot even love somebody whom he really loves.

\section{OUTLINE OF THE CREATIVE WORK}

My creative work is in a form of novel around 170 pages. It will be divided into one chapter for prolog and seven chapters for the plot, and one chapter for epilogue. In some pages, I included some of my personal photographs, which would help the readers to get more vivid visualization of what I am writing.

\subsubsection{Theme}

My theme deals with knowing true self-identity as a means to fulfill human's needs will bring beneficial effects to the people. My creative work explores the identity crisis that Chinese Indonesian actually faces in this contemporary world and how it affects the people as depicted from the lives of my characters in the novel.

\subsubsection{Plot}

Hero Widjaja is a 24-year old man from a conservative Chinese Indonesian family. In response to May 1998 riots in Jakarta, his family sends him off as a child to Singapore for his own safety at age six. He then resides in Singapore to complete his primary school until his aunt who takes care of her in Singapore passes away. Living separately from his parents since a very young age, Hero feels distant from his family. For years, he has always thought that he is an unwanted child. He somehow thinks that his parents practice favoritism among children, which make him hate the tradition. Like in Chinese tradition, his father loves his brother as the first son in the family, and his mother loves his elder sister because they share the bond as the women in the family. Hero often feels lonely and has never thought that he has a home.

One morning, his father offers him a trip to Mainland China to visit his relatives who live in Quanzhou, China. Driven by his desire to find his true identity, Hero then takes the trip. It then becomes his point of attack to his journey to find his identity. He visits Hong Kong and Macau with his friend, Jason Pang, first. With Jason, Hero learns a lot about Hong Kong and Macau. They visit The Peak, have lunch in a famous restaurant at Jordan, and visit Goldfish Market where Hero has a good memory with his aunt. They also visit Macau, where Hero accidentally bumps into Eri Fujiwara in the Venetian Resort Hotel. Hero then continues to travel to Quanzhou, Fujian province in which he meets his extended family, Huang Li Duan, Wang Qing, and Wendy Wang. In Quanzhou, he learns a lot about Chinese culture from his interaction with the three people.

During his stay in China, Eri Fujiwara, a woman Hero is seeing, suddenly meets him in Quanzhou. She flies to meet Hero in Quanzhou after finishing her work to lead her tour for Japanese people in the Mainland. It gets complicated when Hero's relative is against Hero's relationship with a Japanese girl. Hero's relatives then bring him to visit Beijing, the capital, which Hero happily accepts. After they arrive again in Quanzhou, Hero finds out that he has a very young relative, Wang 
Zhiying, who has suffered from cancer. The kid is locked in a room so that he will not learn his dying condition. Hero starts to get to know the kid, and Hero also learns that the kid wants to see the world like how he used to before he is sick.

In the end, Hero is seen writing a journal to commemorate his trip. He tells that Zhiying passes away in his trip to get medication in Germany. He also discusses on how through the trip and his conversation with Jason Pang and his relatives, he can finally understand that he is not like people in Mainland China. He starts to construct his own understanding on his identity as a Chinese Indonesian man.

\subsubsection{Characterization}

\section{Hero Widjaja (24) \\ Nationality \\ Indonesian \\ Chinese Name \\ 黄光平 / Huáng Guāngpíng}

Hero is the youngest of 3 children in the family. His personality is rather melancholy and a thinker. He grows up as a loner because of some personal issues related to his traumatic past of May 1998 riots. At the age of six, he moves to Singapore to live with his relatives for his own safety related to the riots and lives there until he finishes his primary school.

Living in a foreign country, in the edge of his golden ages without his parents, Hero feels he loses parental figures and feels distant from his parents. He lives in Singapore with an auntie named Heidi. When Hero starts to think that Heidi can replace his loss of parental figure, Heidi becomes a victim of a traffic accident in Kallang, Singapore. As a result, Hero finds the absence of comfort in his life again, which leads him to obsession with suicide. He resents what-so-called Chinese culture that his parents inherited from Chinese immigrants for the reason that he senses there is a tendency of favoritism among children, especially for the first sons, in the family.

\section{Hartono Widjaja (28)}

Nationality

Indonesian

Chinese name

黄光明 / Huáng Guāngmíng

Hartono Widjaja is the heir of Widjaja's family business. He is the first son and second child of the family. As the heir of the family business, he works very hard for the family. He tends to be expressive in expressing his love towards his little brother and elder sister. At the same time, he is often involved in arguments with his father, although his father loves him so much as his first son.

Hartini Widjaja (31)

Nationality

Indonesian

Chinese name

黄美亮 / Huáng Měiliàng

Hartini is the eldest child of the Widjaja's family. She is the most favorite child of the mother. During May 1998 riots, she moves to Singapore with Hero for her own safety. After a year, mother asks her to go back because she misses her so much and thinks that Indonesian has been as safe as before for them to live.

In her adulthood, Hartini is married to rather a poor guy according to the father, making him feel disappointed in her. Her father doesn't like the relationship, so he plans to ask Hartini to cancel the wedding less than a week away from the actual date.

Ng Piet Hong (63)

Nationality

Indonesian

Chinese name

黃必峰/ Huáng Bìfēng

$\mathrm{Ng}$ Piet Hong is the father in the Widjaja family. He is the second generation of Chinese immigrants in Indonesia. As the first son of a wealthy Chinese Indonesian family, he is the most spoiled kid among all the children. He is a bit childish as a father and materialistic. He expects his children to obey all he says, regardless that sometimes it is not acceptable for them. When something is different from what he expects it to be, he will try to change it as what he wants no matter what. He values money the highest among all. As a typical conservative Chinese Indonesian father, he really loves the second child, Hartono, because Hartono is the first son.

Melisa Hoo (58)

Nationality

Indonesian 
Chinese name

何瑞美/ Hé Ruìměi

Melisa Hoo is the mother in the family. Unlike Ng Piet Hong, she comes from a pretty modern Chinese Indonesian family background and has many relatives living abroad, one of which is Heidi.

Eri Fujiwara (24)

Nationality

Japanese

Eri is a Japanese young lady that Hero is romantically linked with. She works as a tour guide, which enables her to travel a lot. In Hero's trip to Macau, she bumps into Hero at The Venetian Resort Hotel. He then asks for Hero's address in Quanzhou and goes to Quanzhou to meet Hero and his relatives. Unfortunately, Hero's relatives do not like her.

Jason Pang (26)

Nationality

Hong Kong

Jason Pang is a son of Hong Kong property tycoon. He is one of only a few friends Hero has. Jason is a gym freak. He owns a gym centre in Causeway Bay, Hong Kong. Throughout Hero's trip to Hong Kong and Macau, Jason is the one accompanying Hero. Hero learns a lot about Hong Kongers, Macanese people, as well as Chinese people from Jason.

Wendy Wang (34)

Birth Name

Nationality

Lin Hui Yu

Chinese

Wendy is the daughter of Piet Hong's elder sister. She is cheerful and a bit talkative. She has the best English skill among the Chinese relatives, so Wendy talks to Hero pretty often. She also serves as the translator for other Chinese relatives to Hero. She is married to Wang Qing.

\section{Wang Qing (36)}

Nationality

Chinese

Wang Qing is the husband of Wendy Wang. He is friendly but does not speak good English. $\mathrm{He}$ is friendly to Hero and always tries to speak to Hero although they have language barrier in the first place.

Huang Li Duan (67)

Nationality Chinese

Huang Li Duan is the elder sister of Piet Hong. She is a typical Chinese lady. She is tall for a woman, around $170 \mathrm{~cm}$ and does not speak English. However, she is very kind to Hero and really wants to speak with Hero. Wendy serves as her translator whenever she wants to speak with Hero.

Wang Zhiying (10)

Nationality Chinese

Wang Zhiying is a son of Wendy and Wang Qing. He is suffering from leukemia. He is locked in a room by his family in order to avoid him knowing he has deathly disease. He speaks good English for a boy in his age and likes Hero

\subsubsection{Settings INDONESIA \\ Surabaya}

This is the hometown of Hero Widjaja's family. It will be the place where his family resides and the setting where first part of the novel is mostly located. In Surabaya, the story is mostly located on the Central Surabaya and West Surabaya.

The Widjaja parents live in Central Surabaya, precisely on Raya Darmo street. It is the street where old moneys in Surabaya usually live. Hartono also lives in the Raya Darmo house, whereas Hero lives separately in Graha Famili, West Surabaya. It is a rather newer neighborhood with very expensive price. For a modern man who is interested in real estate and interior design, Hero instantly chooses to live in the neighborhood because of the sophisticated facilities it offers around the new satellite town of West Surabaya.

Jakarta

Hero and the family often visit Hartini who lives in Jakarta, around Kemang neighborhood. Hartini and Hero also visit Skye Rooftop Bar at M. H. Thamrin street and Plaza Indonesa.

MAINLAND CHINA 
Quanzhou - the protagonist's ancestral home where he meets his relatives for the first time - and Beijing, the capital where he finds out that he is proud of becoming a Chinese Indonesian deep inside in his heart. He visits Tiananmen Square, seeing people really respect where the soldiers hold the flag ceremony and guard in all over Beijing with their hearts.

Hong Kong - Hero stays in Tsim Sha Tsui. He will also travel to Mong Kok, Central, and Tsim Sha Tsui area.

Macao - a special administrative of China with Portuguese influence. In Macao, Hero stays in Venetian Macao Resort Hotel. He also explores around the city around Senado Square and Ruins of St. Paul.

CAMBODIA - It is in the very beginning where Hero is told that he once wants to commit suicide. He chooses Angkor Wat area in Siem Reap, particularly in the Angkor Wat temple, as a place to commit suicide in the dawn.

\section{CONCLUSION}

\subsection{Lessons Learned}

Almost one semester finishing this creative work, I also learnt a lot of important things to make a good book from my advisor, chairperson, and examiner. It was such a very valuable journey to finish my very first book completely. Among other things, I learnt how to make a good sentence so that my readers can understand the idea I want to convey completely. I also learnt to conduct a good research and cite properly in order to avoid plagiarism. I realize it will be very helpful for me to be able to write an academic writing better in the future.

In writing this creative, I conducted several researches and interviews some people, which also enriches my understanding in knowing Chinese Indonesian culture more. Throughout the writing process, I also learnt to be more sensitive to understand culture and tried to explain that appropriately in words. Since my main character is educated in Singapore, I also tried to research and finally mastered some British English spelling and idioms, in which I do not normally use, in order to make my project more convincing and give the precise cultural background.

\subsection{Future Plans}

Since I had only limited time, which is one and a half month, in order to write this novel intensively aside from the researches, I realized that this creative project must have flaws. For my future plans, I hope that someday I can finally be able to publish my creative project into an autobiographical novel commercially after several other revisions and further researches. Throughout my writing process, I really began to understand more how important it is to know our self-identity. As a Chinese Indonesian man, there was the time when I was confused about my identity in Indonesia's contemporary society. Writing this novel helps me construct my views on finding self identity as well, so I really hope that one day I can share what I have found out in the process of writing this creative project and help other people who might be facing the same problem in terms of finding their self-identity.

\subsection{Suggestion / Recommendation}

For those who have read this project, I hope I can make them become more aware of how important it is to know our identity and embrace it in order to live a better life. As this creative work is far from excellence, I also encourage my readers who have the same interest in Chinese Indonesian culture and identity to take the same step to write the same topic in a better way since this topic is very worth discussing.

\section{REFERENCES}

Bachrun, R., Hartanto, B. (2000). Krisis identitas diri pada kelompok minoritas Cina. In Wibowo (Eds.), Harga yang harus dibayar: Sketsa pergulatan etnis Cina di Indonesia. Jakarta: Gramedia Pustaka Utama dan Pusat Studi Cina.

Chandradinata, P. (2009, September 18). Kebudayaan etnis Tionghoa ditinjau dari tujuh unsur kebudayaan universal. Retrieved September 1, 2016 from: http://peterrchandradinata.blogspot.co.id/2009/09/kebudayaan-etnis-tionghoa-ditinjaudari_18.html 
Crain, W. C. (2011). Theories of development: Concepts and applications ( $6^{\text {th }}$ ed.). Upper Saddle River, NJ: Pearson Education, Inc.

Doyen, B. (2007). What is a memoir? What makes a memoir different from an autobiography or biography?. Retrieved September 1, 2016 from: http://www.barbaradoyen.com/writingnonfiction/what-is-a-memoir-what-makes-a-memoir-different-from-an- autobiography-orbiography

Gross, F. L. (1987). Introducing Erik Erikson: Aninvitation to his thinking. Lanham, MD: University Press of America.

Hernandez, S. M. (2015, April 15). How to write a memoir: 6 creative ways to tell a powerful story. Retrieved September 1, 2016 from: http://thewritelife.com/how-to-write-a-memoir/

Houston, T. (2012, February 29). Autobiographical fiction: Using your real life to craft great fiction. Retrieved September 1, 2016 from: https://litreactor.com/columns/autobiographical-fictionusing-your-real-life-to-craft-great-fiction

Macnow, A.S. (2014). MCAT behavioral science review. New York City: Kaplan Publishing.

Schultz, D.P., \& Schultz, S.E. (2009). Theories of personality, $9^{\text {th }} E d$, New York: WadsworthCengage Learning.

Showalter, S. (2012, September 11). Why is there a surge in memoir? Is it a good thing? Retrieved September 1, 2016 from: https://janefriedman.com/memoir-trend/

Susetyo, D.P.B. (1999, June 1). Asimilasi etnis Cina di era reformasi. Surat kabar harian Solo Pos. Retrieved September 1, 2016 from http://budisusetyo-inside.blogspot.co.id/2010/01/krisisidentitas-etnis-cina.html

Susetyo, D.P.B. (2002). Stereotip dan relasi antar etnis Cina dan etnis Jawa pada mahasiswa di Semarang. (Unpublished master's thesis). Universitas of Indonesia, Depok, Indonesia.

Thayalamoorthy, K., \& Ratchagar M. (August 8, 2016). Autobiographical elements in the novel Five Point Someone by Chetan Bhagat. Retrieved August 8, 2016 from www.languageinindia.com/aug2016/thayalafivepointsomeone.pdf

Wahyudi, I. (2013). Yang orisinil lebih menarik, Retrived September 1, 2016 from: http://www.kompasiana.com/iwanwahyudi/yang-

orisinillebihmenarik_552a0f81f17e615452d623ce 